\title{
Detection of Land Use and Land Cover Changes for New Cairo Area, Using Remote Sensing and GIS
}

\author{
El-Sawy K. El-Sawy ${ }^{1}$, Atif M. Ibrahim², Mohamed A. El-Bastawesy ${ }^{3}$, Waleed A. El-Saud ${ }^{4}$ \\ ${ }^{1}$ Geology Department, Faculty of Science, Al-Azhar University (Assiut Branch), Assiut, Egypt \\ ${ }^{2}$ Geology Department, Faculty of Science, Al-Azhar University, Cairo, Egypt \\ ${ }^{3}$ National Authority for Remote Sensing and Space Sciences, Cairo, Egypt \\ ${ }^{4}$ Hajj Research Institute, Umm Al-Qura University, Makkah, Saudi Arabia
}

\begin{abstract}
New Cairo district, Egypt, is one of the main regions undergoing extensive development. Identifying and describing the urban sprawl in this region over the past development periods is essential for any future planning through implementing policies to optimize the use of natural resources and accommodate development whilst minimizing the impact on the environment. In this work the change between land cover components in the area have been analyzed, focusing on the expansion of the urban patterns and rock units between 1984 and 2014 using Landsat satellite image. The relationships between the geomorphology, natural resources and anthropogenic influences (human activates) have also been considered. Ground survey data and field observation are used to investigate the environmental changes in the area. Three Landsat satellite images acquired in 1984, 2013 and 2014 have been analyzed. Results from this study indicate that the urban area had expanded to forty times its 1984 size. The sedimentary covered decreased during the 30year period from about 918, 821 to $655 \mathrm{Km}^{2}$ for the years 1984, 2003 and 2014 respectively.
\end{abstract}

Keywords: GIS, Spatial Data, Change Detection, Urbanization, Sustainable Development

\section{Introduction}

New Cairo area and its surroundings, lies in the eastern part of the metropolitan area of Greater Cairo. It extends between longitudes $31^{\circ} 25^{\prime}$ to $31^{\circ} 55^{\prime} \mathrm{E}$ and latitudes $29^{\circ} 55^{\prime}$ to $30^{\circ}$ $10^{\prime} \mathrm{N}$ (Figure 1) and cover about $932.85 \mathrm{~km}^{2}$, it encompassing major parts of the new cities; include Bader, El-Shorouk and Highkstep cities, (Figure 1). These New urban settlements have been developed around Greater Cairo, as one of the third generation of cities built in Egypt to try and solve the population problem and redirect urbanization away from the Nile Valley. The New Cairo has developed incrementally since the mid-1980s as a result of future government vision to create some new urban communities around the main Cairo city.

New Cairo area is considered as the eastward extension of theGreater Cairo Region (GRC), which represents the main historical, economical and urban pole of Egypt since its establishment more than 1000 years ago. GRC is the main seat of Egyptian government as it contains most of the main services and facilities that have contributed to the excessive growth of the region. The high rate of population growth within GRC, which demands for land reclamation for further city expansion. Some of the unplanned and unmanaged expansion projects in the area resulted in serious environmental degradation processes. The development of urban built-up area of greater Cairo region from 1900, 1950, 1970 and 2000 is $42 \mathrm{~km}^{2}, 120 \mathrm{~km}^{2}, 198.2 \mathrm{~km}^{2}$ and $524.4 \mathrm{~km}^{2}$ respectively, addingmore than $270 \%$ of urban built-up to the city during the last three decades [1].

In 1983, a long-term development master plan started by the Ministry of development and construction and GOPP with the aid of IUERIF and OTUI French consultancy firms [1]. The Plan aimed basically at controlling the rapid growth of population in GCR and using the private sector dynamism and resources to support the physical planning process [2]. The plan assured the importance of the implementation of the ring road, in addition to the establishment of the "New Towns". The concept aimed at transferring the massive urbanization process from agricultural land to desert area by creating different economic and social incentives to attract population [3]. Seven main new cities were established; 6th October, 15th of May, El-Obour, El-Shorouk, New Cairo, Bader, and 10th of Ramadan. 


\section{International Journal of Science and Research (IJSR) \\ ISSN (Online): 2319-7064}

Index Copernicus Value (2013): 6.14 | Impact Factor (2014): 5.611

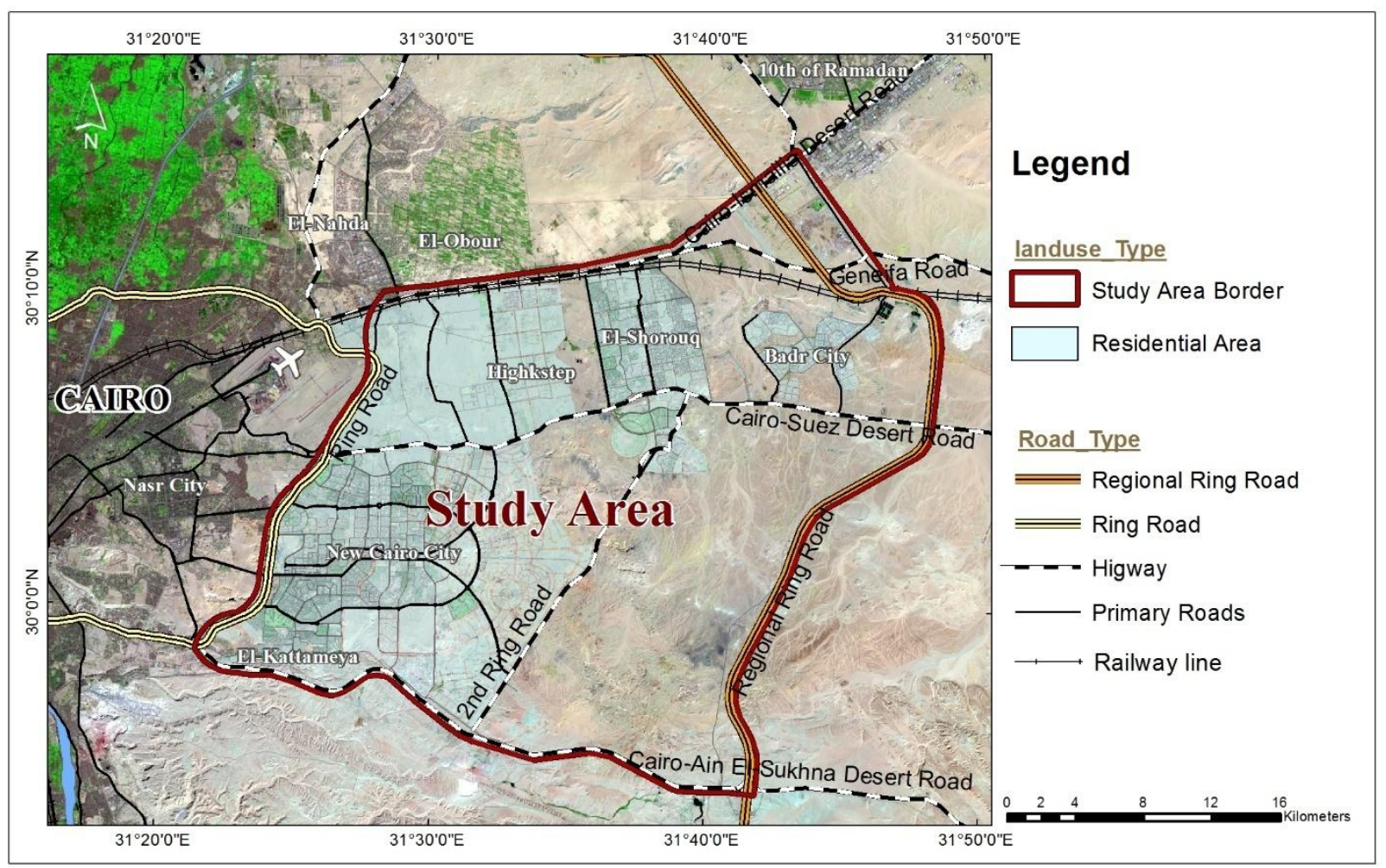

Figure 1: Location map of the study area

In the vicinity of the study area, the 10th of Ramadan wasthe first urban city constracted to the eastern desert of GCR, in 1984. Since this time, new settlements were erected in the zone surrounding the greater Cairo area, especially to the eastern flank of Greater Cairo due to its distance from the main city and the suitablenessof both topographic and geologic setting of the area. All of these reasons make the study area more suitable for urban expansion.

The establishment of New Cairo city passed through four stages; the beginning at mid-1980s, three settlements among out of ten that were suggested around Greater Cairo region (El-Tagamoa ,,first, third and fifth ${ }^{\text {eee }}$ were established. In this time, the city acquired great fame among the new urban settlements due to its distinctive developed location. Requests from investors increased on such distinctive land as to their location near to the Ring Road and the districts of Nasr City and Heliopolis, the decree was issued in 1995 to establish the city that was composed of the existing three settlements and the areas between them in addition to the eastern extensions. In 1997 another decree was issued by adjusting the extensions of the city once more. It was established with a Presidential decree number (191) for the year 2000 the eastern parts were annexed to the cordon of the city, leasing it to some private and public companies. The decree was successive by adding some other areas to the cordon of the city without a final settling on the total area of the city. The urban settlements allowed huge areas of lands to be available, which attracted investments to buy thousands of acres and establish housing projects [4].

The objective of this work is to investigate the environmental changes using multi-temporal, multispectral remote sensing data to identify changes at NCR caused by the anthropogenic influences.The will provide good assessment regarding the impact of the recent development activities in area and its environmental impact on the overall ecological conditions of the urban environment [5]. Remote sensing data and geographic information systems (GIS) provide ideal data sources for large-area land cover classifications and change detection [6]. They are considered as a powerful and cost-effective tools for assessing the spatial and temporal dynamics and changes in land cover and land use [7; 8]. In Egypt, remote sensing and its applications have emerged as early as this technology was invented. Early studies were based on visual interpretation of MSS data to map sand accumulations in the Western Desert [9]. During 1980s, soil salinization was a good target to be monitored using satellite images [10]. Advanced image processing was observed in the literature during 1990s as many specialists applied image classification, principal component analysis and digital change detections[11; 12]. Advanced techniques for mapping land cover change detection, such as vegetation indices and water indices were applied in research since late 1990 until now [13; 14].

\section{The Study Area}

The study area crossed by the Cairo-Suez railway and CairoIsmailia road to the north and Cairo Ain El-Sukhna asphaltic road to the south, between them, the Cairo-Suez desert road is located (Figure 1). This road is running in an east-west direction to close between both Cairo and the regional ring road in the east. The area located east of the Nile Delta flood plains, which be differentiated into a high, medium and low relief units and sloping regionally northward. In the south at latitude $30^{\circ} 00^{\prime}$ a series of highly elevated plateaux of hard persistent limestone are present, ranging from $150 \mathrm{~m}$ (Gebel Mokattam) to $870 \mathrm{~m}$ (Gebel Ataqa). Due northward and between latitude $30^{\circ} 00^{\prime}$ and $30^{\circ} 15^{\prime}$, the area under

\section{Volume 5 Issue 2, February 2016}




\section{International Journal of Science and Research (IJSR) \\ ISSN (Online): 2319-7064 \\ Index Copernicus Value (2013): 6.14 | Impact Factor (2014): 5.611}

investigation is characterized by an isolated low hills of darker tones and a series of relatively less resistant elongated ridges, mostly oriented in WNW-ESE and E-W directions. The average altitudes of these ridges range from $150 \mathrm{~m}$ to $200 \mathrm{~m}$ above sea level, and their lengths range from 20 to 50 $\mathrm{km}$. These ridges followed northwards by a wide plain, which is drained generally into a north to northwest direction by many water courses, which start generally from the south, southwest and southeast (Figure 2). The ridges are built up of sandy limestone, gravels, sands and basalts.

Stratigraphically, the study area is covered by a sedimentary succession ranging in age from upper Eocene to Recent; The Upper Eocene rocks are composed of shelly sandy limestone, dolomitic limestone and sandy marl, with thin clay laminae. They form the southern area along the Cairo Ain El-Sukhna road and scattered outcrops at Gebel ElNassuri and El-Anqabiya in the central area, of about 60 to $100 \mathrm{~m}$ thick. The Oligocene rocks are represented by continental sands with silicified wood and gravels as well as volcanic basalt sheets. They are exposed in the area located to the east. Miocene sediments are mainly composed of sands, sandstones, flints, pebbles, gravels and sometimes some sandy limestones with tow Shallow marine facies of Hommath and Geneifa Formations. Sands and calcareous sandstone interbedded with clay and sandy limestone of Pliocene sediments lies unconformably over the Marine Miocene and are mostly coveredby the Quaternary deposits $[15 ; 16 ; 17 ; 18 ; 19 ; 20]$ (Figure 3 ).

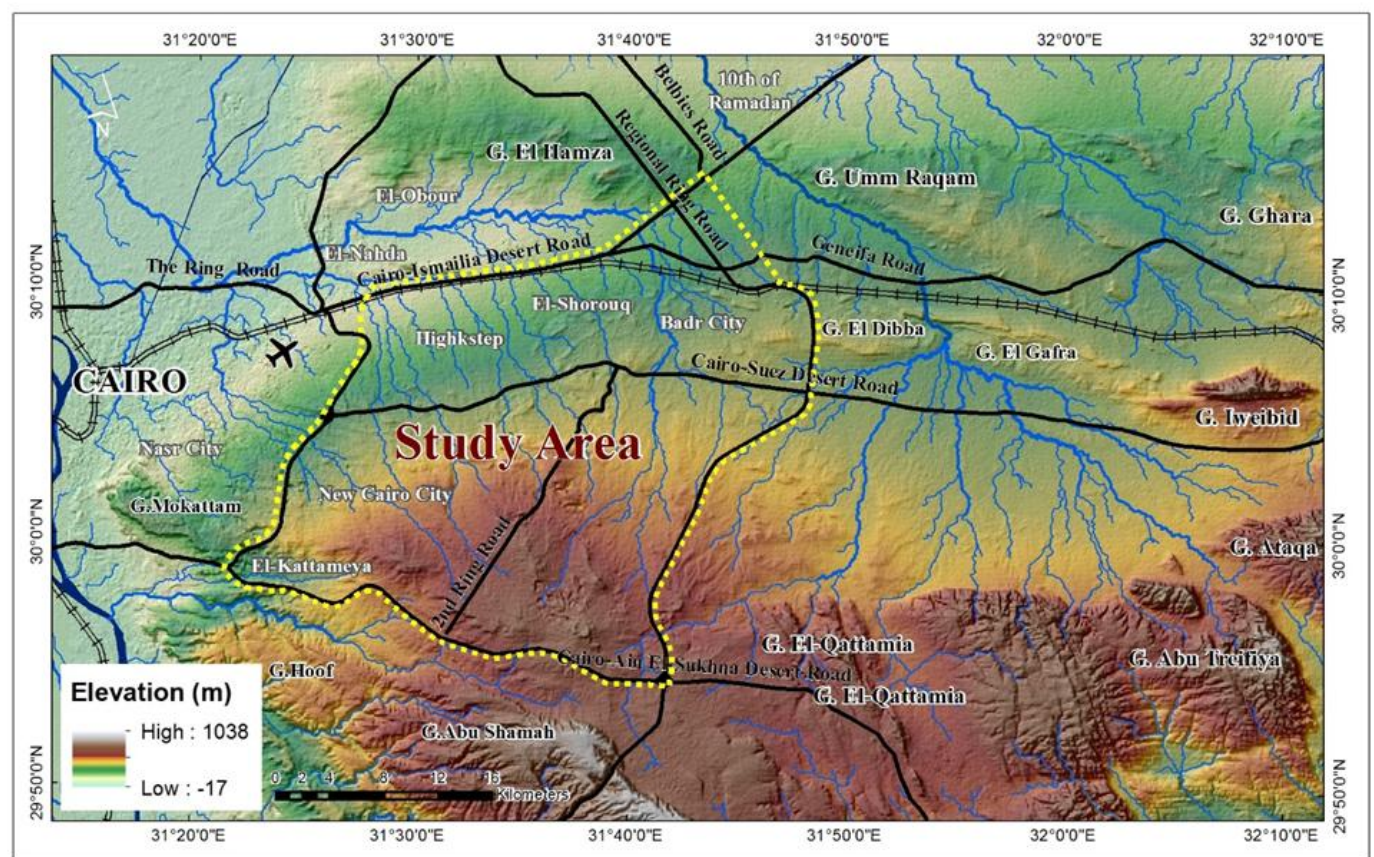

Figure 2: Shuttle Radar Topography Mission (SRTM) generated digital elevation model (DEM) for the study area showing the variation in topography.

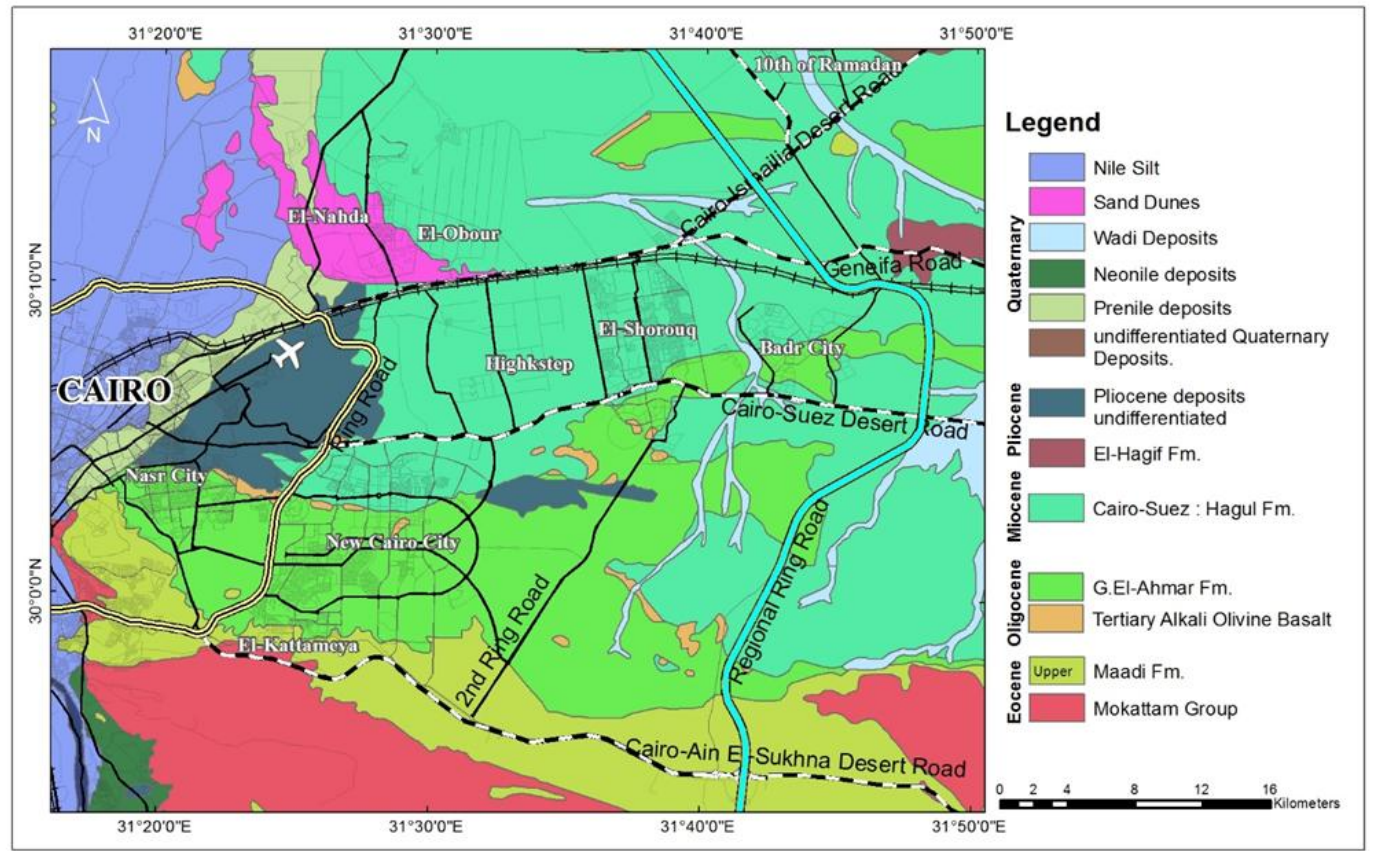

Figure 3: The geological map of the study area, north Eastern Desert (digitized from Conoco, 1987) [20].

Volume 5 Issue 2, February 2016 


\section{International Journal of Science and Research (IJSR) \\ ISSN (Online): 2319-7064}

Index Copernicus Value (2013): 6.14 | Impact Factor (2014): 5.611

\section{Methodology}

To accomplish the objectives of the present study, old and as well as the most available and recent images have been used in order to map landscape change in New Cairo area between 1984 and 2014 to analyze the direction of urban sprawl on the northern part of eastern desert. Three available satellite Landsat Images were obtained from the United States Geological Survey (USGS) online resources [21]. Landsat Thematic Mapper (TM) images acquired in May 1984, Landsat 7 ETM+ image acquired in August 2003 and Landsat 8 Operational Land Imager (OLI) acquired in February 2014 were used to detect changes in the study area. The topographic maps prepared by the Egyptian Military Survey at scale 1: 50,000 have also been used in addition to our field investigations. All the images were originally georeferenced to the Universal Trans-verse Mercator (UTM, zone $36^{\circ} \mathrm{N}$ ). Atmospheric correction was applied to remove the dust and haze effect from each subset image for subsequent classification. To monitor and analyses the dynamic expansion and change detection in the area east of
GCR, many remote sensing techniques applied by using Erdas Imagine 2014, ArcGIS 10.3 software packages. Land use and land cover image classifications were constructed with high accuracy for each of the individual classes of the land cover units.

The present study is constructed based on the processing of Landsat dataset, which represent one of the most valuable spatial data for understanding the global land cover status. This type of data is freely provided by the United States Geological Survey (USGS) over the Internet (http://earthexplorer.usgs.gov/). In this study, three Landsat images(Landsat 5, 7 and 8 - path/row: 176/39)for different time periods(1984, 2003 and 2014 respectively) are used (Figure 4: False color composite image (bands 7, 4, 2 in RGB) for the Landsat images acquired in (a) 1984, (b) 2003 and (c) 2014 respectively showing the urban expansion of New Cairo area.

; a, b and c).

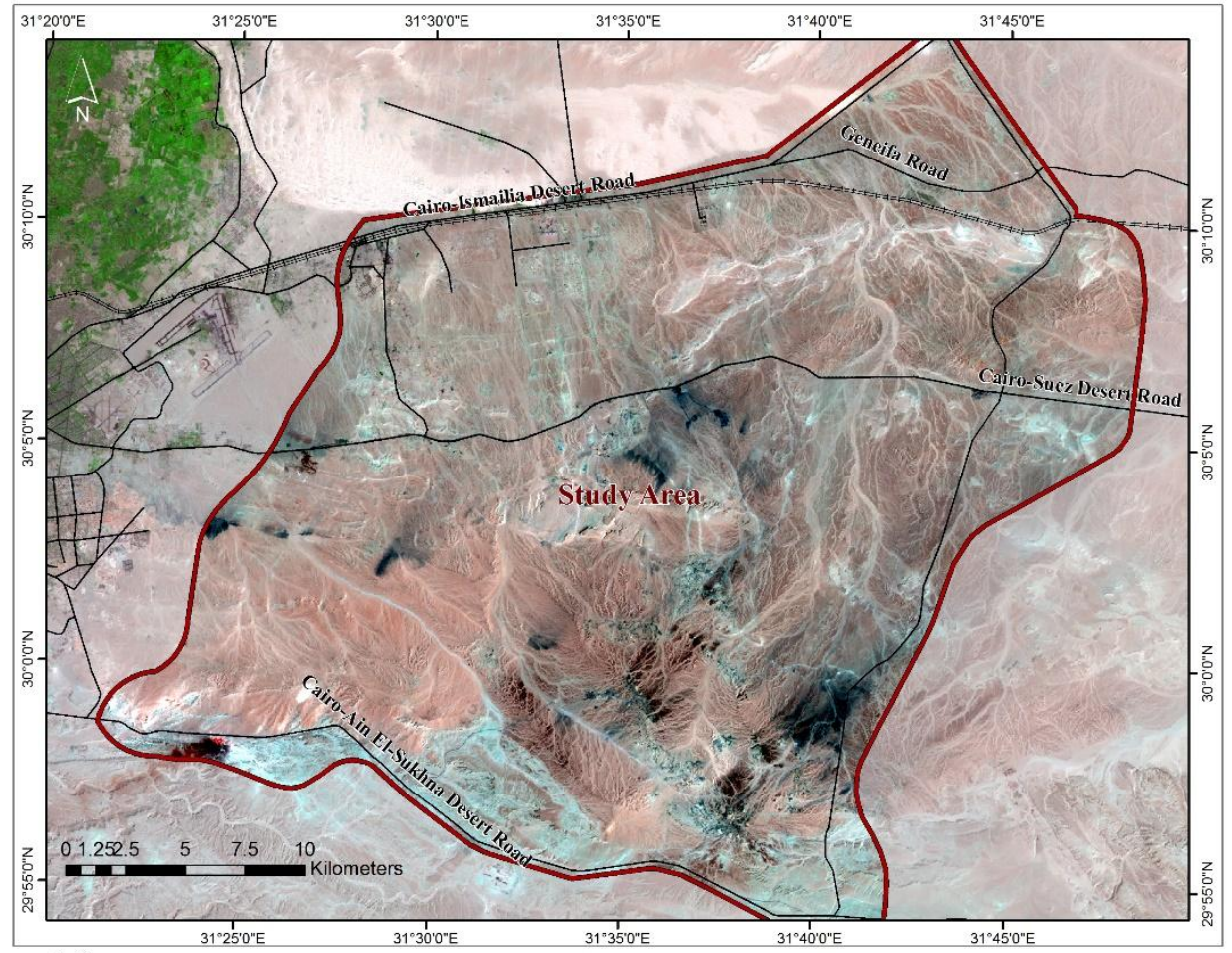

(a) TM (1984) 
International Journal of Science and Research (IJSR)

ISSN (Online): 2319-7064

Index Copernicus Value (2013): 6.14 | Impact Factor (2014): 5.611

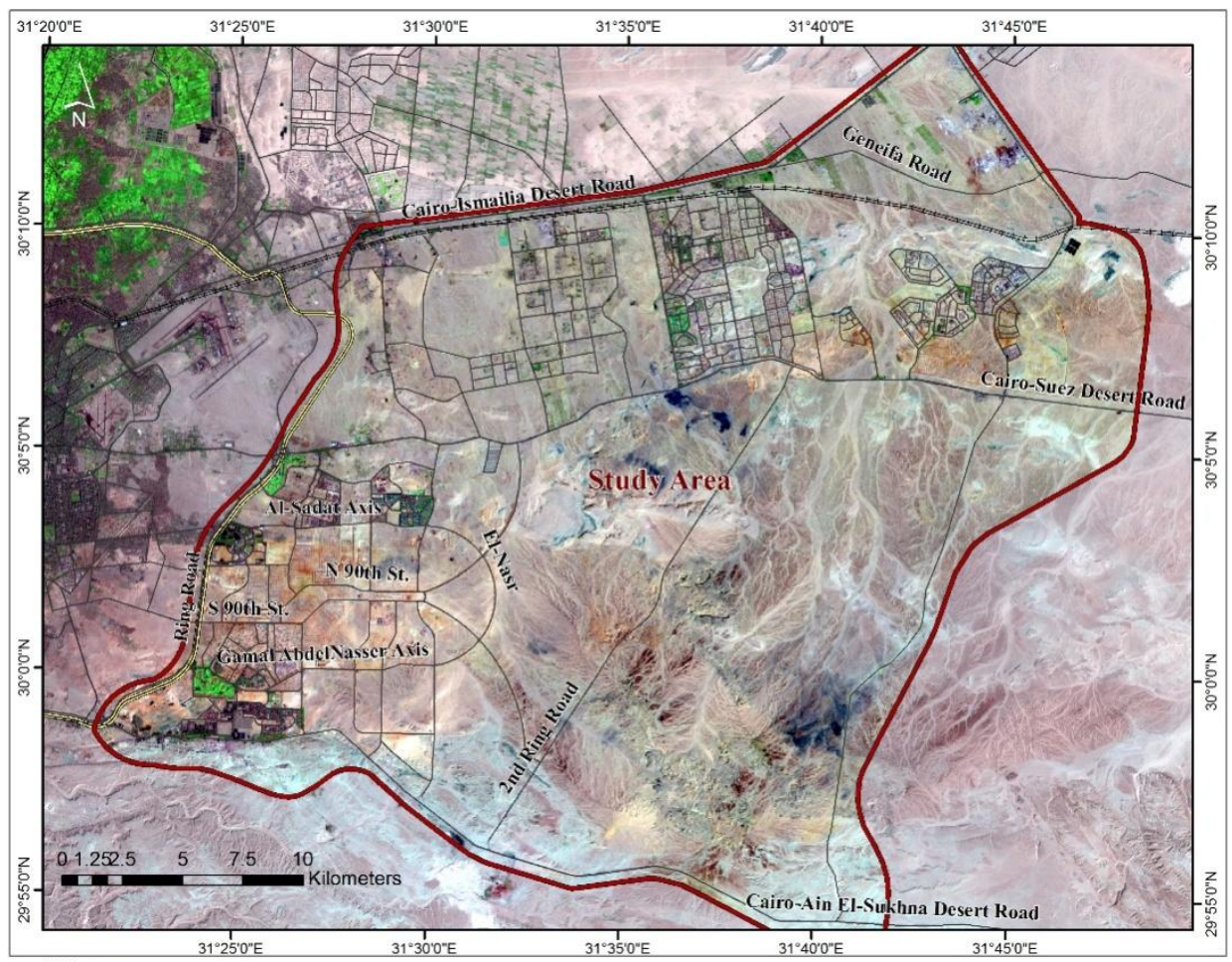

(b) $\mathrm{ETM}+(\mathbf{2 0 0 3})$

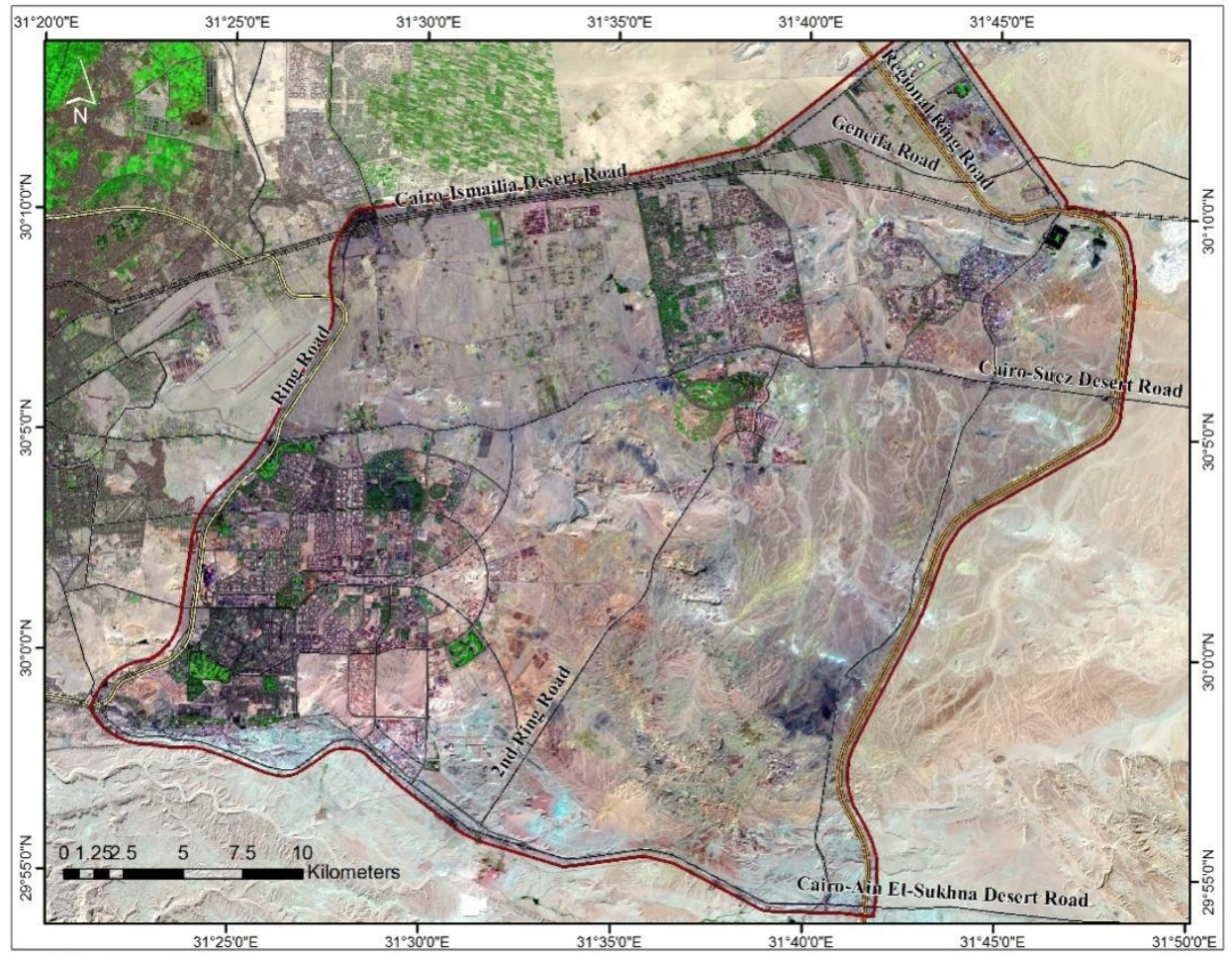

(c) AOL (2014)

Figure 4: False color composite image (bands 7, 4, 2 in RGB) for the Landsat images acquired in (a) 1984, (b) 2003 and (c) 2014 respectively showing the urban expansion of New Cairo area.

The Landsat image classification isapplied based on field observations to collect and validate the data from each of the different classes. The surface geology of the area has been taken into account since they will be affected by the urban expansion in the land cover changes. Land use data of the study area have been collected from their primary sources e.g. the records of the housing and building, National Research Center and New Urban Communities Authority, Cairo, Egypt. Extensive field verification, ground surveying and literature review records have also been applied for the different land use classes.

There are various methods of addressing change detection using satellite images [22]. The post-classification change detection technique is one of the most common, accurate and quantitative techniques [23]. In this study, the ground truth points used for assessing the accuracy of the classifications were selected using high resolution SPOT images and field investigation using a Global Positioning System (GPS)

\section{Volume 5 Issue 2, February 2016}




\section{International Journal of Science and Research (IJSR) \\ ISSN (Online): 2319-7064 \\ Index Copernicus Value (2013): 6.14 | Impact Factor (2014): 5.611}

unit.A post-classification technique based on hybrid classification (unsupervised and supervised) is used. Each method used was assessed, and checked in the field. Unsupervised classification was carried out on the three datasets separately, using a histogram peak cluster technique to identify dense areas or frequently occurring pixels [24; 25]. The cluster module was carried out firstly for fine generalizing level clustering, retaining all spectral classes. It was planned to extract 43 classes especially for most modern scene (Landsat data acquired in 2003 and 2014), butbecause the urban surfaces are heterogeneous and composed of a complex combination of features (e.g. buildings, roads, grass, trees and soil)some urban settlements have been misclassified due to the fact that they displayed similar spectral characteristics.Field examination of the individual classes helped in detecting some of the signature differences between various units in the satellite images. Grouping of the units from various categories into 10 main classeswas necessary to produce the land cover map of the study area

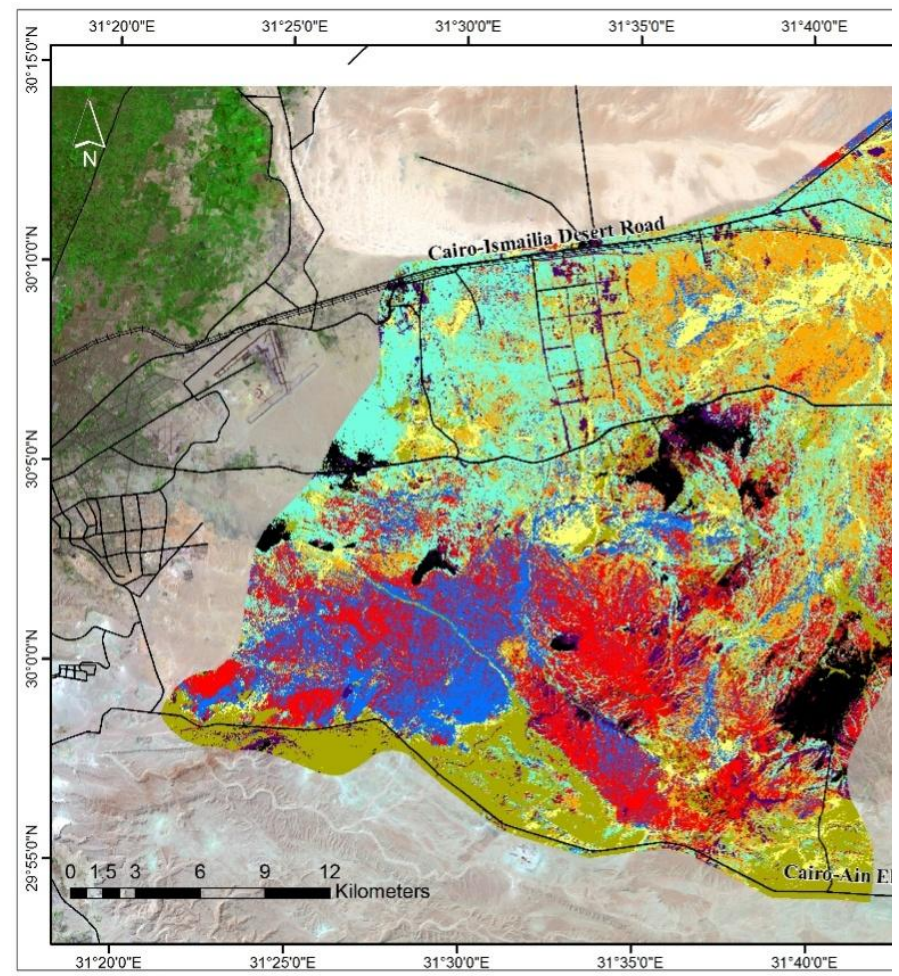

(a) TM (1984) with high classification accuracy. These classes include; sedimentary rocks outcrops, urban areas, agricultural/green area, and roads. A supervised classification is performed taking into account the surfaces that have similar spectral signatures using the data collected during the field survey.Representative sampleshave been selectedfor each of the classes with 30 training sites (signatures) acquiredfor each class. A spectral signature file for each class was subsequently created. These signature files were used by maximum likelihood classifier to categorize the continuum of spectral data in the entire image. All pixels pertaining to each class were recoded together and the gross area of this class was counted [25].

\section{Results and Discussion}

Using unsupervised and supervised classification, 10 landuse/land-cover classes were produced for the classified images with only 8 available in the 1998 image (

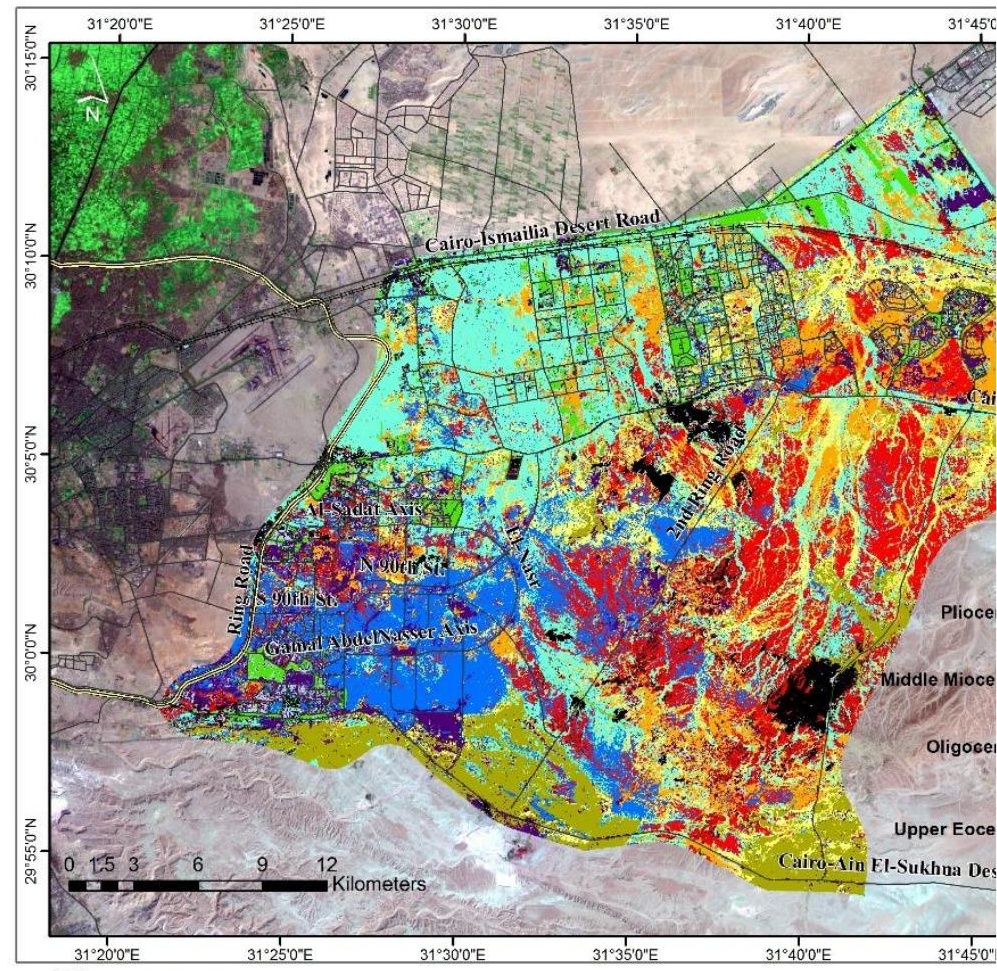

(b) $\operatorname{ETM}+(2003)$ 


\section{International Journal of Science and Research (IJSR) \\ ISSN (Online): 2319-7064}

Index Copernicus Value (2013): 6.14 | Impact Factor (2014): 5.611

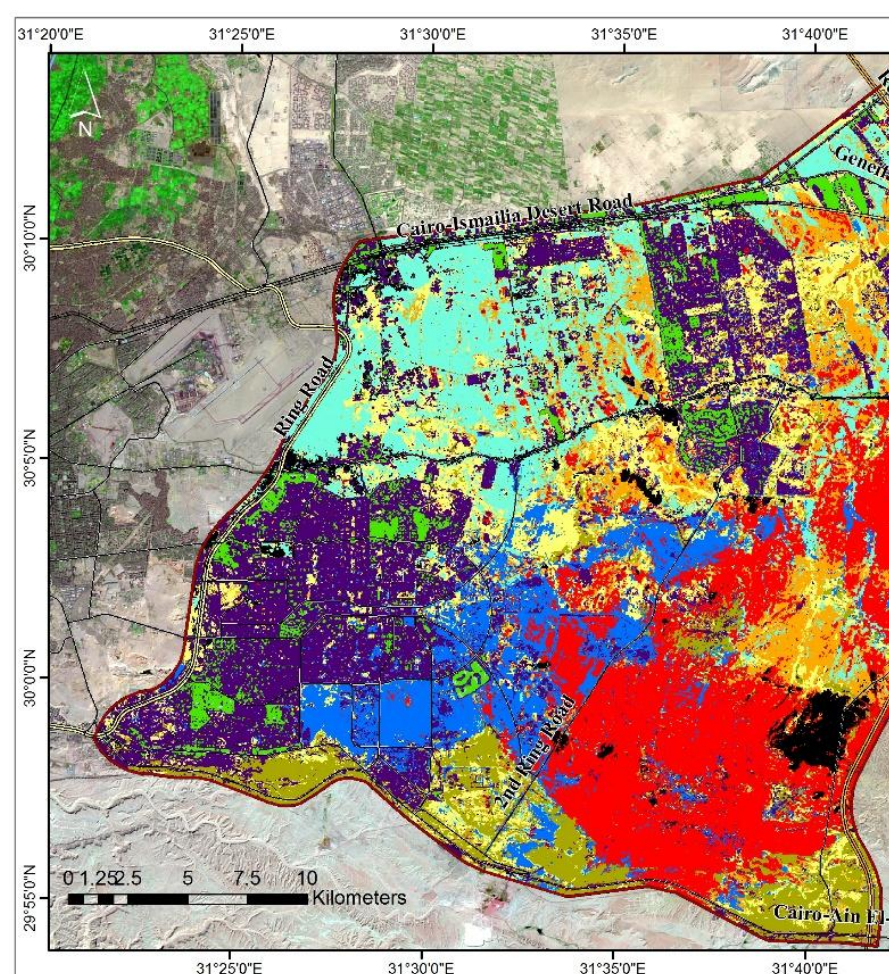

(c) AOL (2014)

Figure 5) (Figure 6).Table 1 shows a list of the extracted classes, note that thewater bodies and the green areas are not available in the 1984 image.The resulted land cover maps show a tremendous and rapidly expansion of the urban areas toward the north, east and northeast direction. Urban areas had expanded to 40 times its 1984 size.Urban areas started with $15.02 \mathrm{~km}^{2}$ in (1984) and expanded to about $55.171 \mathrm{~km}^{2}$ in (2003) to reach about $226.018 \mathrm{Km}^{2}$ in (2014). Between (1984) and (2014), $251 \mathrm{~km}^{2}$ of new urban areas have been added to the eastern part of Greater Cairo. This can be attributed to the establishment of three new settlements; ElTagamoaAl-Awal, Al-Thalith and Al-Khamis. Between 2003 to 2014 the area attracted the invistors to establish numerous housing projects plus the ones already established by the Cairo governorate. The rapid increase in the class of green areasmay be attributed to this expansion. The tradeoff between the urban areas, green land and sedimentary covers are shown in (Figure 7) and (Table 1). The growing rate (percentage) of each class in the study area through the three selected years are represented in (Figure 8). The sedimentary cover decreased during the 30 -years period from 917.85 and $820.64 \mathrm{Km}^{2}$ to about $654.60 \mathrm{Km}^{2}$ for the years of 1984,2003 and 2014 respectively. The overall accuracy of the classification procedure was estimated by calculating the percentage of the classified pixels (those pixels in the major diagonal of the matrix) from the total number of pixels of all classes. This indicated how reliable the training areas were in representing the land-cover/land-use classes. The overall accuracy estimated for the classified images was greater than $95 \%$.

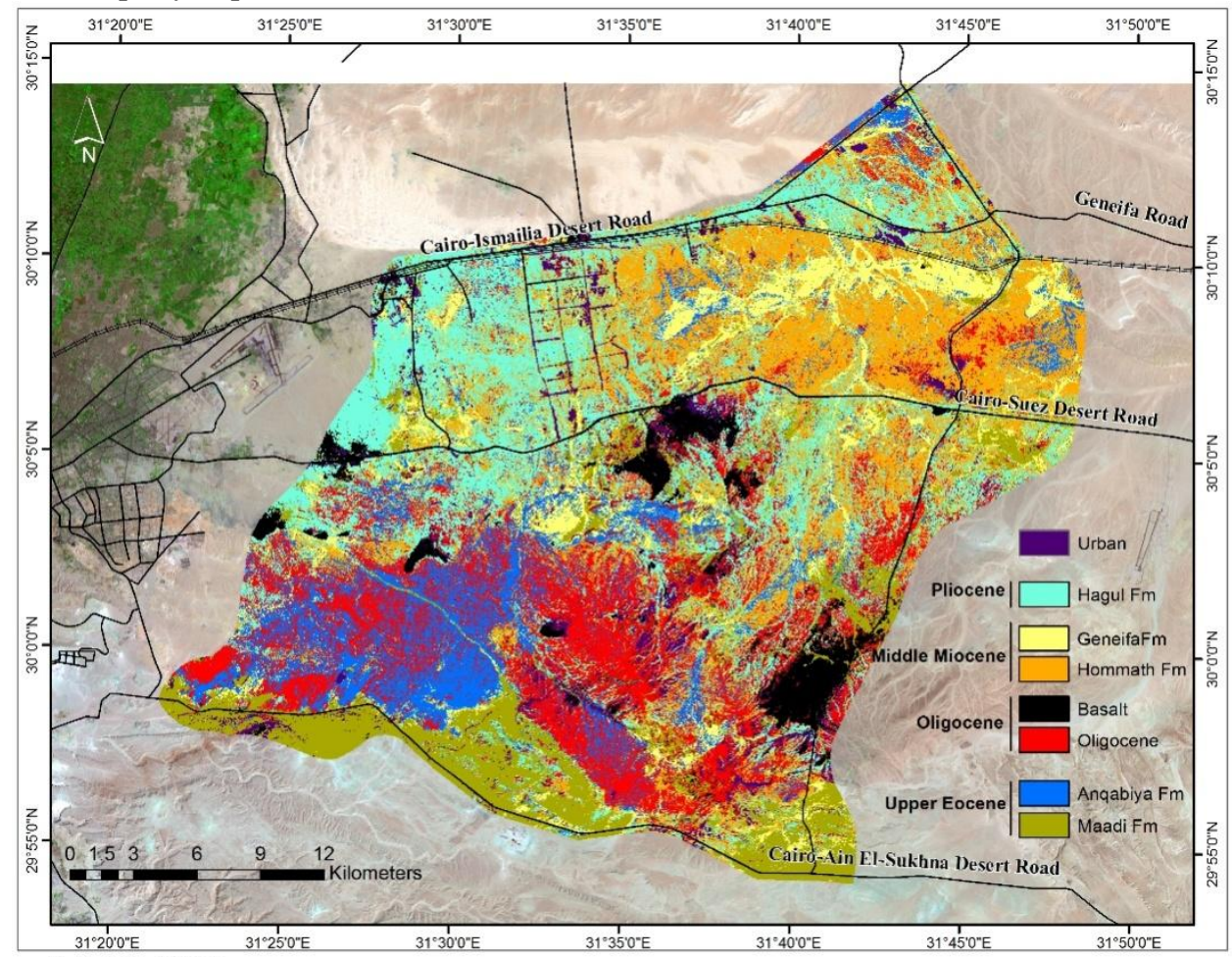

(a) TM (1984) 


\section{International Journal of Science and Research (IJSR)}

ISSN (Online): 2319-7064

Index Copernicus Value (2013): 6.14 | Impact Factor (2014): 5.611

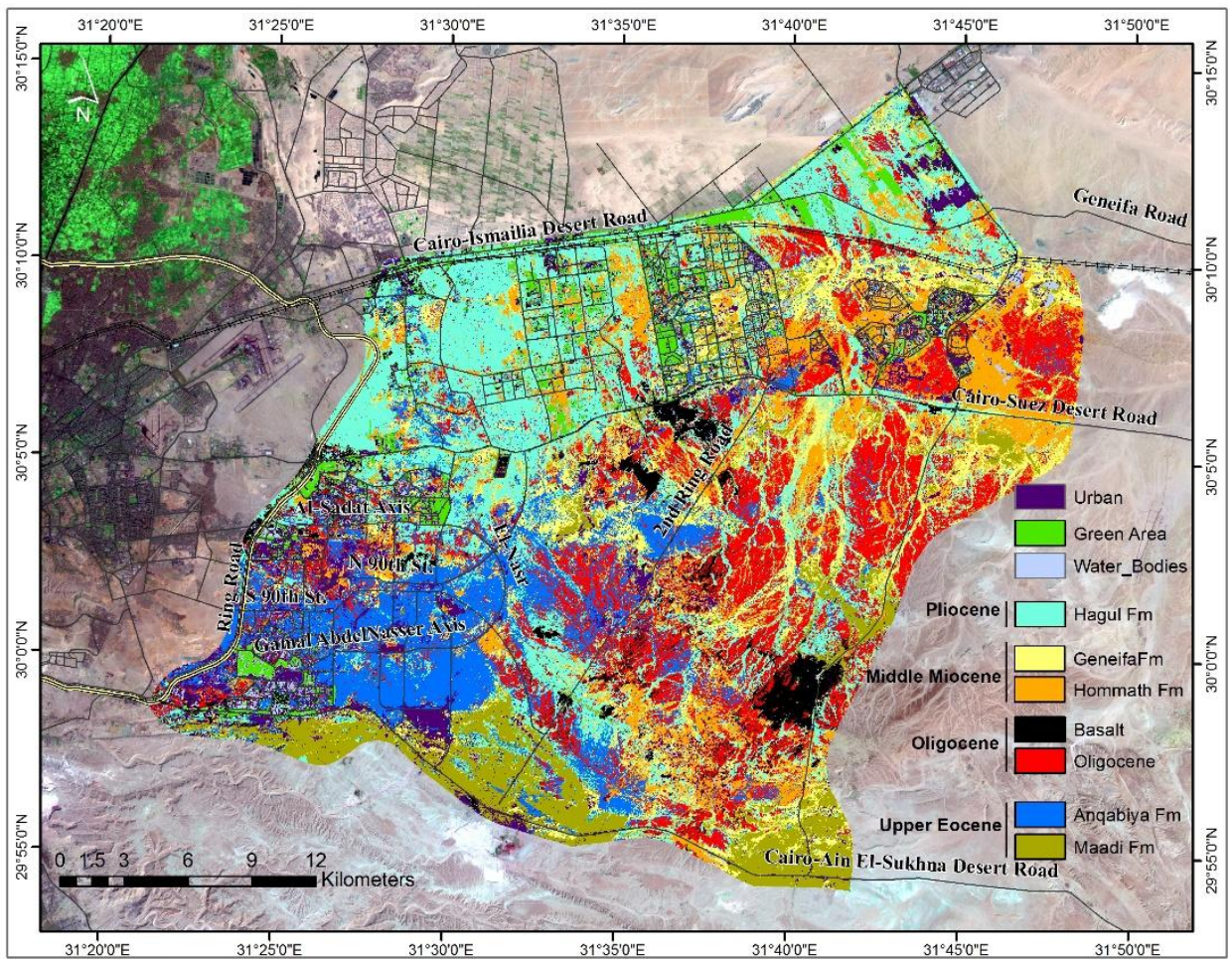

(b) $\operatorname{ETM}+($ 2003)

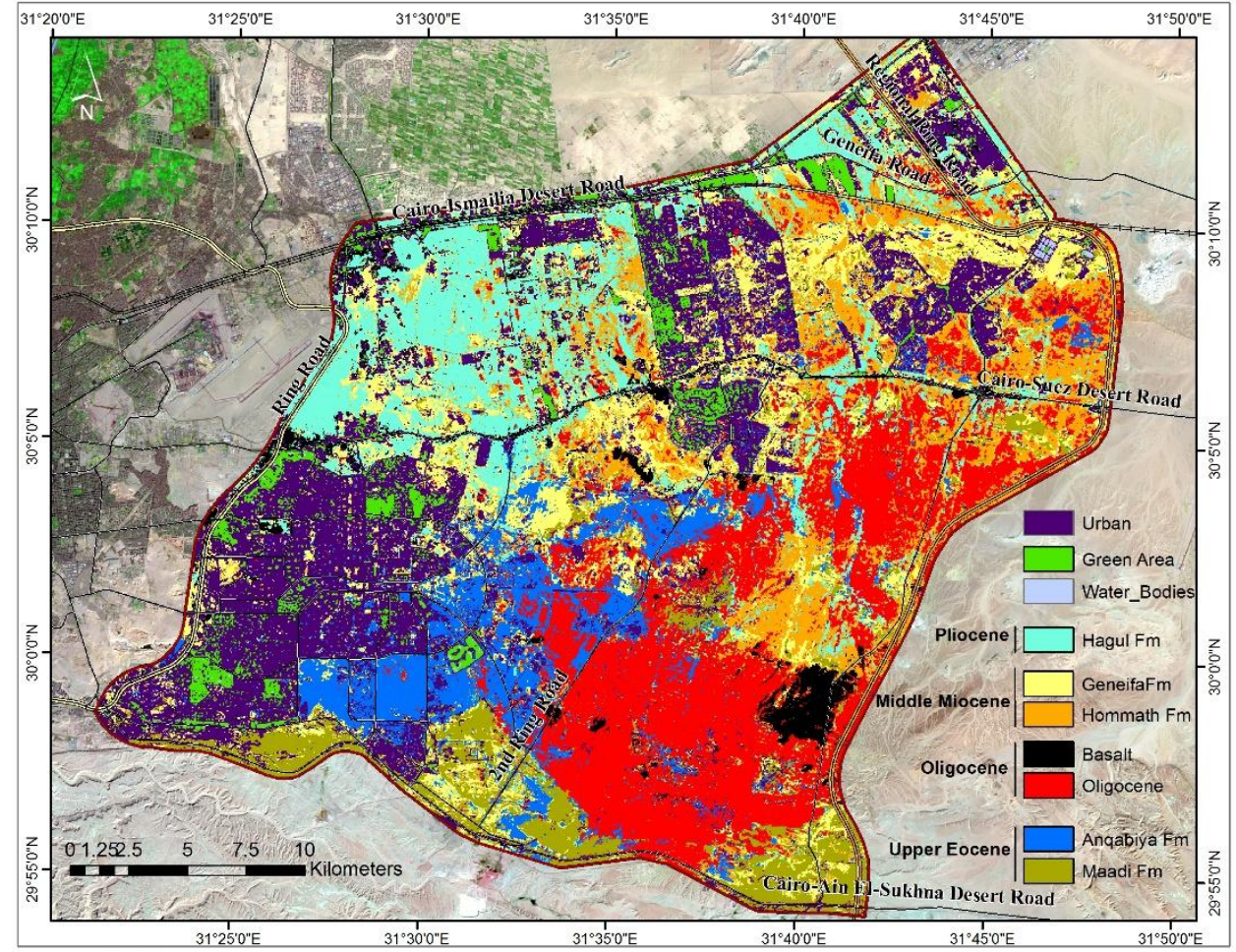

(c) AOL (2014)

Figure 5: Land use/land cover multitemporal supervised classified images representing the changes between (a) 1984, (b) 2003 and (c) 2014 data respectively. 
International Journal of Science and Research (IJSR)

ISSN (Online): 2319-7064

Index Copernicus Value (2013): 6.14 | Impact Factor (2014): 5.611
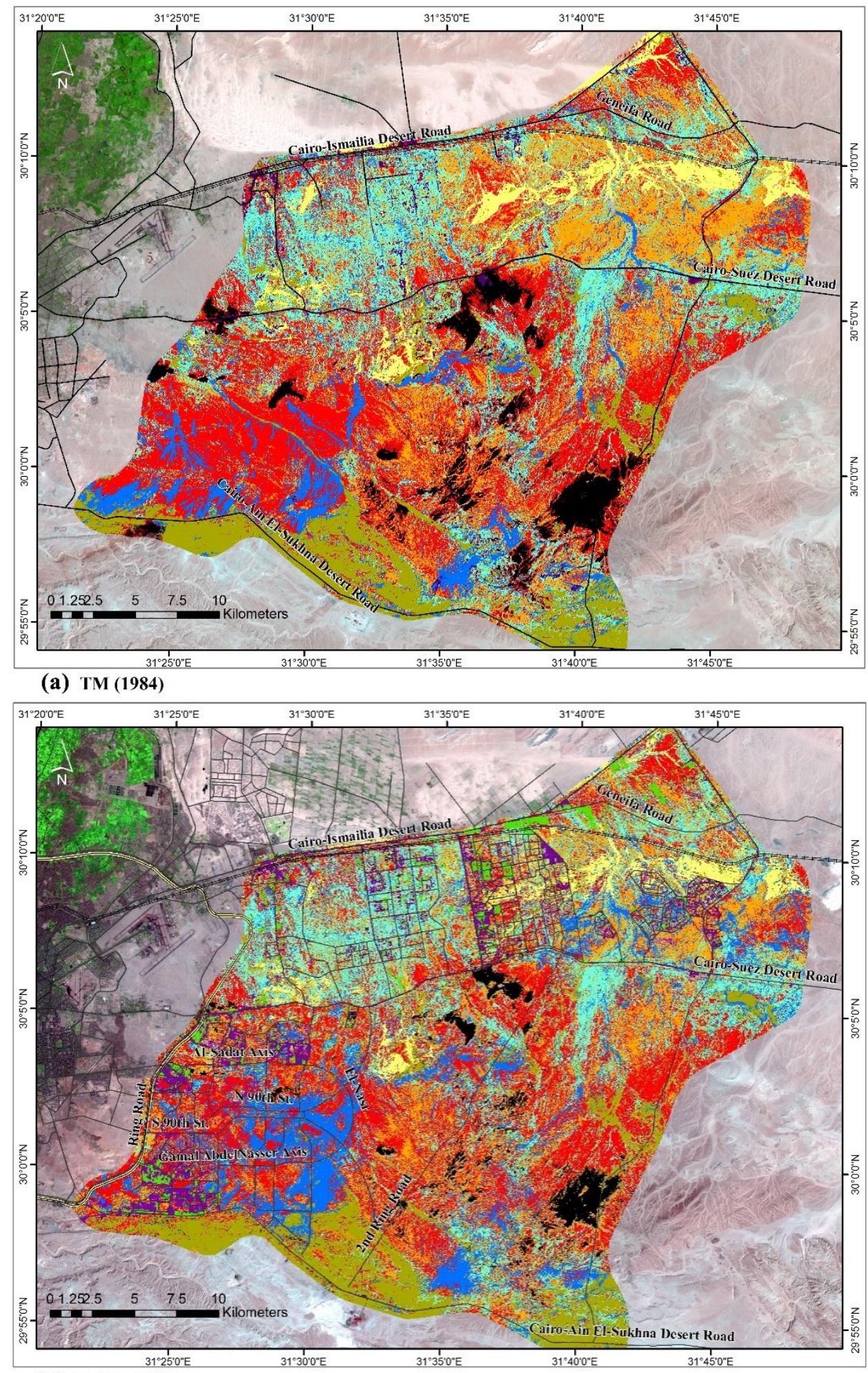

(b) $\mathrm{ETM}+(2003)$

Volume 5 Issue 2, February 2016

www.ijsr.net 


\section{International Journal of Science and Research (IJSR) ISSN (Online): 2319-7064}

Index Copernicus Value (2013): 6.14 | Impact Factor (2014): 5.611

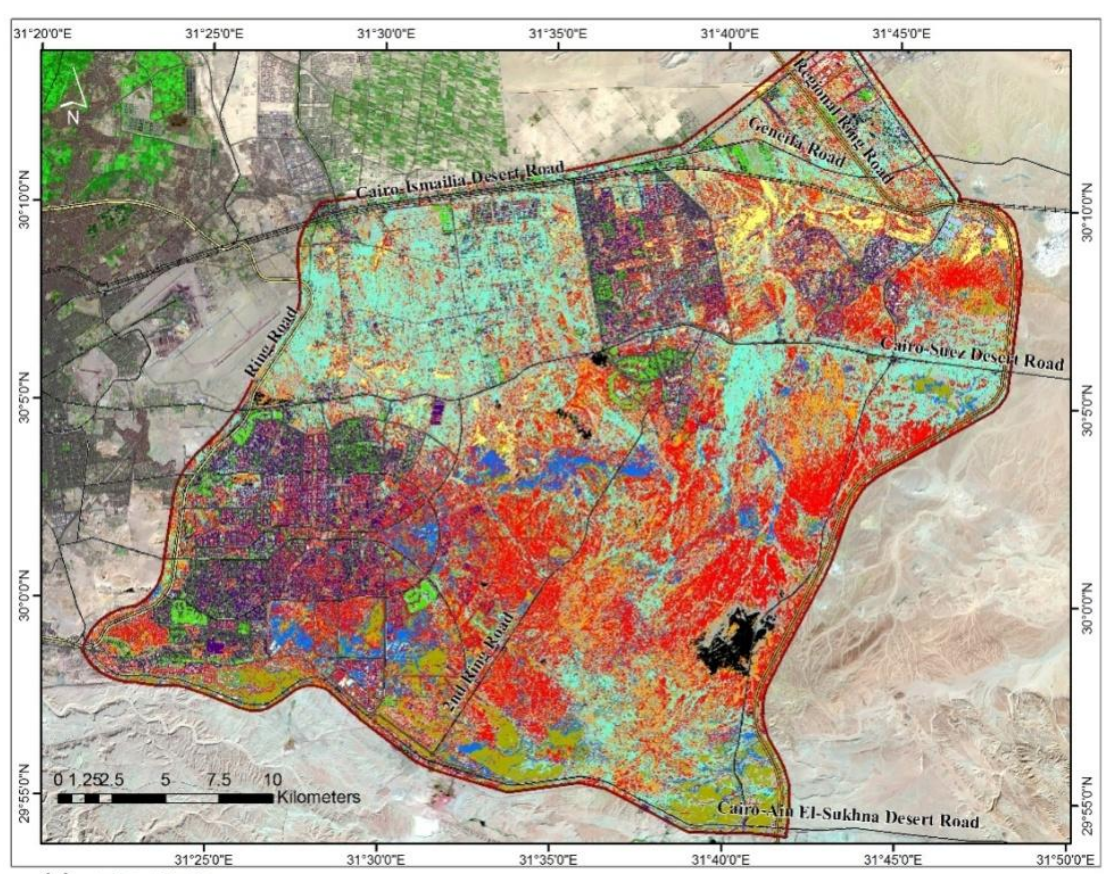

(c) AOL (2014)

Figure 6: Land use/land cover multitemporal unsupervised classified images representing the changes between (a) 1984, (b) 2003 and (c) 2014 data respectively.

Table 1: The land cover changes in $\mathrm{Km}^{2}$ in 1984-2003-2014 and the proportions of each class to the completely studied area.

\begin{tabular}{|c|c|c|c|c|c|c|c|}
\hline $\begin{array}{l}\text { Class } \\
\text { no. }\end{array}$ & Classes & $\begin{array}{c}\text { Land-use/land- } \\
\text { cover (1984) Km² }\end{array}$ & $\begin{array}{c}\text { Cover } \\
\%\end{array}$ & $\begin{array}{c}\text { Land-use/land- } \\
\text { cover }(2003) \mathrm{Km}^{2}\end{array}$ & Cover $\%$ & $\begin{array}{c}\text { Land-use/land-cover } \\
(2014) \mathrm{Km}^{2}\end{array}$ & Cover $\%$ \\
\hline 1 & Water Body & - & - & 21.385 & 2 & 1.03 & 0.1 \\
\hline 2 & Agriculture & - & - & 35.256 & 4 & 51.202 & 5 \\
\hline 3 & Urban Area & 15.02 & 2 & 55.171 & 6 & 226.018 & 24 \\
\hline \multicolumn{8}{|c|}{ Pliocene } \\
\hline 4 & (Hagul Fm.) & 200.142 & 21 & 207.012 & 22 & 109.075 & 12 \\
\hline \multicolumn{8}{|c|}{ Middle Miocene } \\
\hline 5 & (Geneifa Fm.) & 88.804 & 10 & 107.766 & 12 & 124.923 & 13 \\
\hline 6 & (Hommath Fm.) & 189.77 & 20 & 104.563 & 11 & 109.173 & 12 \\
\hline \multicolumn{8}{|c|}{ Oligocene } \\
\hline 7 & Basalt & 52.15 & 6 & 48.8 & 5 & 16.664 & 2 \\
\hline 8 & (G. Ahmar Fm.) & 187.168 & 20 & 159.607 & 17 & 157.442 & 17 \\
\hline \multicolumn{8}{|c|}{ Upper Eocene } \\
\hline 9 & (Anqabiya Fm.) & 87.546 & 9 & 112.68 & 12 & 77.743 & 8 \\
\hline 10 & (Maadi Fm.) & 112.277 & 12 & 80.217 & 9 & 59.585 & 6 \\
\hline Sum. & 932.859 Km² & & & & & & \\
\hline
\end{tabular}

\section{Each classarea in $\mathrm{Km}^{2}$ at the time of analysis}

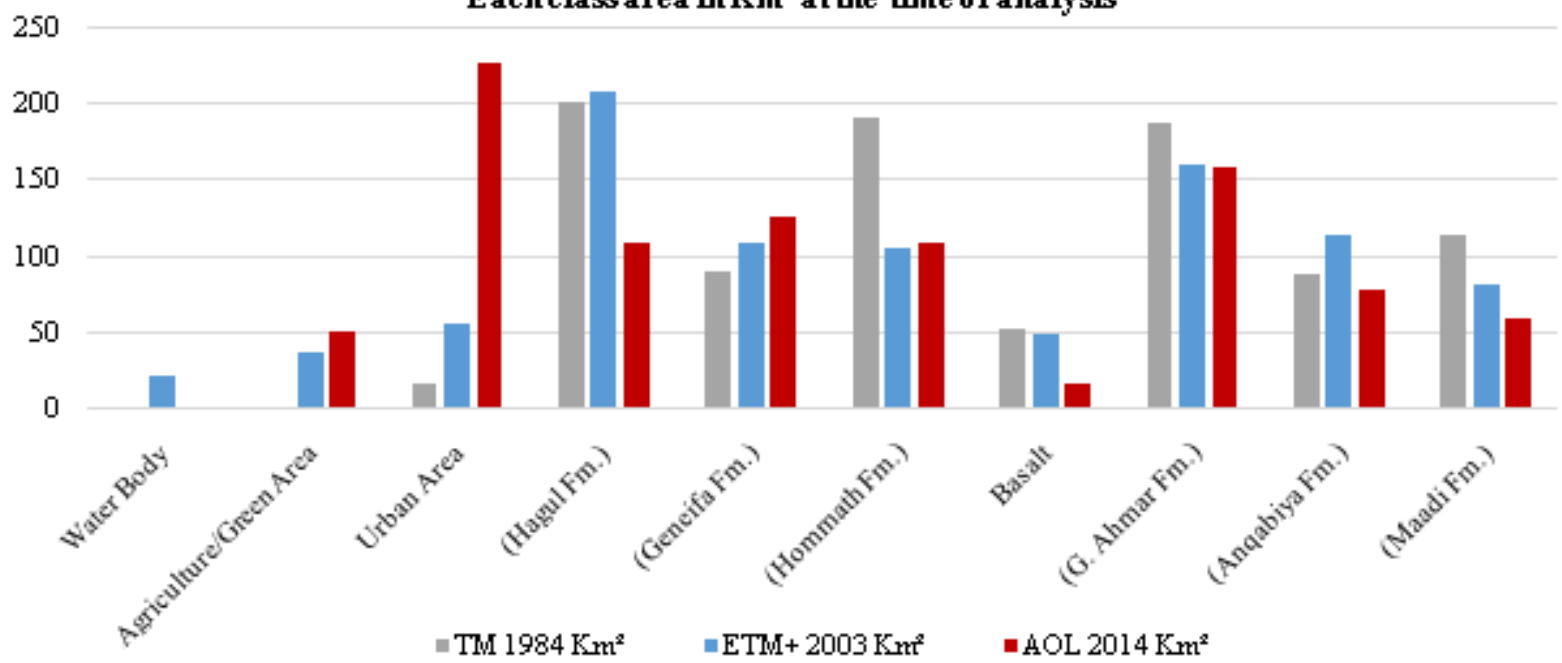

Figure 7: Histogram showing the changes in the surface area for each of the individual classes (in $\mathrm{Km}^{2}$ ) in the study area, at the time of analysis.

Volume 5 Issue 2, February 2016 


\section{International Journal of Science and Research (IJSR) \\ ISSN (Online): 2319-7064}

Index Copernicus Value (2013): 6.14 | Impact Factor (2014): 5.611
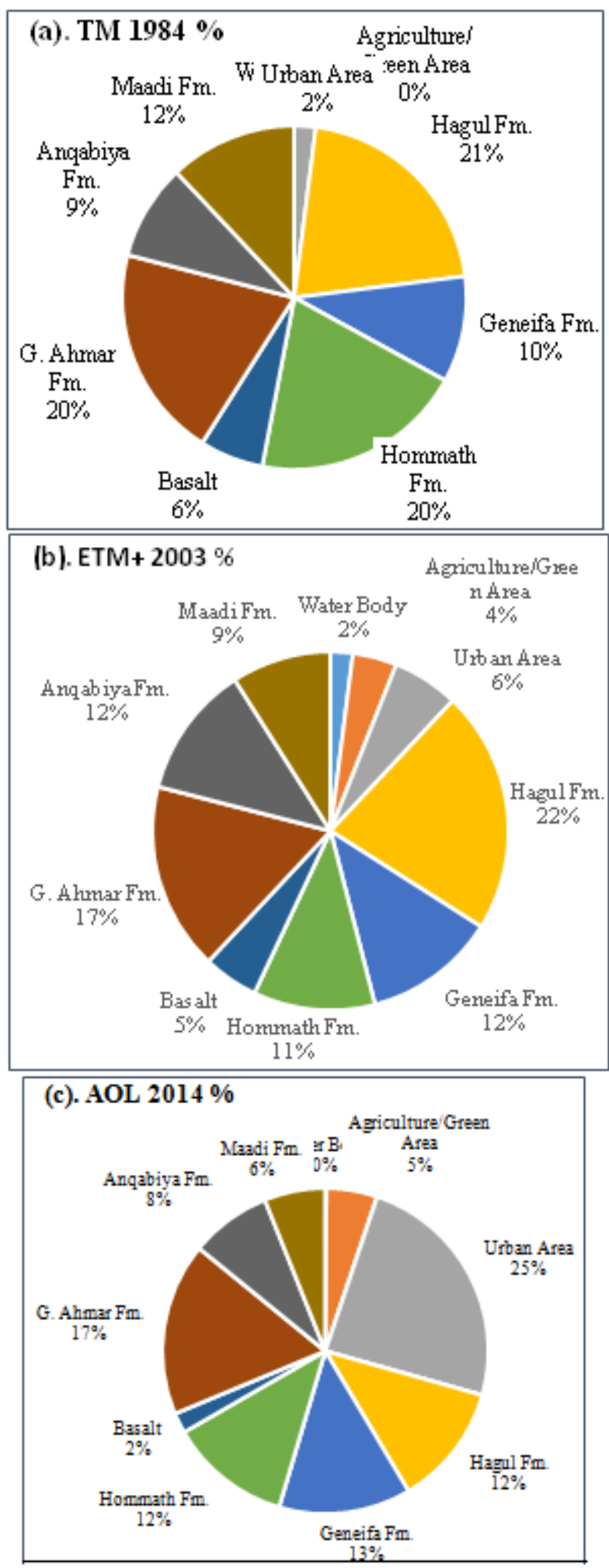

Figure 8: The Percentage of each class in the study area in the years (a) 1984, (b) 2003 and (c) 2014 respectively.

\section{Conclusion}

Change detection using classification techniques (both unsupervised and supervised) of the Landsat time seriesis proven effective for monitoring the dynamics changes of urban expansion in the new cities as well as its associated sedimentary cover. As an attempt to investigate environmental changes using multi-temporal, multispectral satellite data to identify changes caused by anthropogenic influences. The present study shows an integration between geographic information system and remote sensing analytical tools used in an effective method to analyze and understand spatial and temporal dynamics of land cover changes, and to provide valuable information necessary for planning and development especially in arid regions. Results from this study show a very rapid increase in the urban areas that reached about 40 times when compared to its 1998 pattern. The land cover maps produced in this study may contribute to both the development of the land use planning around the new urban areas as well as the decision making for future forecasting of possible future changes in growth patterns by using the polychotomousregression modeling to predict the land cover in the future.

\section{Author Contribution}

This manuscript is a part of the $\mathrm{PhD}$ thesis of the fourth author under the supervision of the rest of the authors.

\section{References}

[1] El-Kouedi, Hazem, Madbouly, Mostafa and The World Bank, "Tackling the Shelter Challenge of Cities Thinking it Through Together", Cairo, 2007.

[2] Sims, David and Séjourné, Marion, "Understanding Cairo", Cairo, 2006.

[3] United Nations Centre for Human Settlements, "Metropolitan planning and management in the developing world: spatial decentralization policy in Bombay and Cairo", UN HABITAT, Nairoubi, 1993.

[4] Reham M. Hafez, " New cities between sustainability and real estate investment: A case study of New Cairo city", Cairo, 2015.

[5] A. Yeh and X. Li, "Economic Development and Agricultural Land Loss in the Pearl River Delta, China", Habitat International, Vol. 23, No. 3, pp. 373-390. 1999.

[6] Iverson, L.R., Cook, E.A. and Graham, R.L,"A technique for extrapolating and validating forest cover across large regions: Calibrating AVHRR data with TM data",International Journal of Remote Sensing, 10, 1805- 1812, 1989.

[7] S., Hathout, "The Use of GIS for Monitoring and Predicting Urban Growth in East and West St. Paul, Winnipeg, Manitoba, Canada", journal of Environmental Management, Vol. 66, No. 3, pp. 229-238, 2002.

[8] P. Serra, X. Pons and D. Sauri, "Land-Cover and LandUse Change in a Mediterranean Landscape: A Spa-tial Analysis of Driving Forces Integrating Biophysical And Human Factors", Applied Geography, Vol. 28, No. 3, pp. 189-209. 2008.

[9] El-Baz, F., Breed, C.S., Grolier, M.J. and McUauley, J.F., "Eolian features in the western desert of Egypt and some applications to Mars", Journal of Geophysical Research, vol. 84, pp. 8205-8221, 1979.

[10] Abdel-Hamid, M.A., Shreshta, D. and Valenzuela, C., "Delineating, mapping and monitoring of soil salinity in the Northern Nile Delta (Egypt) using Landsat data and geographic information system", Egyptian Journal of Soil Science, vol. 32, pp. 463-481, 1992.

[11]Frify, O.E., Nasr, S.M., El-Hattab, M.M. and El-Raey, M., "Remote sensing of beach erosion along the rosetta promontory, north-western Nile delta, Egypt", 
International Journal of Remote Sensing, vol. 15, pp. 1649-1660, 1994.

[12]Frihy, O.E., Dewidar, K.M., Nasr, S.M. and El-Raey, M.M., "Change detection of the northeastern Nile Delta of Egypt: Shoreline changes, spit evolution, margin changes of Manzala lagoon and its islands", International Journal of Remote Sensing, 19, pp. 19011912, 1998.

[13]Lenney, M.P., Woodcock, C.E., Collins, J.B. and Hamdi, H., "The Status of agricultural lands in Egypt: The use of multitemporalNDVI features derived from Landsat TM", Remote Sensing of the Environment, vol. 56, pp. 8-20, 1996.

[14]El-Asmar, H. and Hereher, M., "Change detection of the coastal zone east of the Nile Delta using remote sensing", Environmental Earth Sciences, vol. 62, pp. 769-777, 2011

[15]A. Osman, "Geotechnical and Structural studies on some new cities around Cairo" Cairo University, Faculty of Science, Geology Department. pp. 411-420, 2010.

[16]I. A. M Frag, and M. M. Ismail,"Contribution to the stratigraphy of the Wadi Hof area (North-East of Helwan)", Bull. Fac. Sci., Cairo, Uni., vol.27, pp. 221239, 1959.

[17]R. Said, "The Geology of Egypt", Elsevier Pub. Co., Amsterdam, p. 377, 1962.

[18]A. R. Moustafa, F. El-Nahhas, and S. Abdeltawab, "Engineering geology of Mokattam city and vicinity, eastern Greater Cairo, Egypt”,Eng.Geol., vol. 31, pp. 327-344, 1991.

[19] A. H. Swedan, "A note on the geology of Greater Cairo area", Annals of the geological survey of Egypt, vol. XVII, pp 239-251, 1991.

[20] CONOCO, "Geological map of Egypt. Scale 1:500 000; Sheet Cairo", CONOCO and the Egyptian General Petroleum Corporation, Cairo, 1987.

[21]USGS. Earth Resources Observation and Science Center (EROS). Available online: glovis.usgs.gov (accessed on 11 February 2014).

[22]Lu, D., Mausel P., Brondiozio, E. and Moran, E., "Change detection techniques". International Journal of Remote Sensing, vol. 25, pp. 2365-2407, 2004.

[23] Singh, A., "Digital change detection techniques using remotely sensed data". International Journal of Re-mote Sensing, vol. 10, pp. 989-1003, 1989.

[24]Lillesand, T.M. and Kiefer, R.W., "Remote Sensing and Image Interpretation", Sec. Ed., John Wiley and Sons, Inc.: Toronto, 1987.

[25] Eastman, J. R., "Supervised Classification in IDRISI for Windows Version 2". Tutorial Exercises (Worcester, Massachusetts: Clark University), pp. 86-94, 1997. 